\title{
CHARACTERISTICS OF PULP OBTAINED FROM MISCANTHUS $x$ GIGANTEUS BIOMASS PRODUCED IN LEAD-CONTAMINATED SOIL
}

\author{
VALENTINA PIDLISNYUK, ${ }^{*}$ TATYANA STEFANOVSKA, ${ }^{* *}$ VALERII BARBASH ${ }^{* * *}$ \\ and TATIANA ZELENCHUK ${ }^{* * *}$ \\ *Jan Evangelista Purkyne University, Pasterova 3632/5, Ústí nad Labem, Czech Republic \\ ${ }^{* * *}$ National University of Life and Environmental Sciences, Kyiv, Ukraine \\ ${ }^{* * *}$ National Technical University of Ukraine, Igor Sikorsky Kyiv Polytechnic Institute, \\ Kyiv, Ukraine \\ \Corresponding author: V. Barbash,v.barbash@kpi.ua
}

Received June 18, 2020

\begin{abstract}
The main goal of the study was to investigate processing of Miscanthus $x$ giganteus biomass produced in soil contaminated with lead and other trace elements (TEs) into pulp using chemical pulping. The phytoremediation parameters of the plant were measured during two growing seasons, which confirmed that the process can be defined as phytostabilization; the contaminants were mainly concentrated in the roots and practically did not translocate to the stalks and leaves, which permitted the use of the aboveground biomass to process into pulp using the organosolvent cooking. The chemical composition, morphological structure, and microscopic characteristics of various crops' stalks were investigated and compared with the same parameters received for wood and other non-wood plant materials: rape, flax, hemp, and wheat straw. Indicators of pulp were studied depending on the duration of the organosolvent cooking. After 90 minutes of the cooking process, the peroxide pulp from M. x giganteus had a breaking length of $8300 \mathrm{~m}$, tear resistance of $310 \mathrm{mN}$, and burst resistance of $220 \mathrm{kPa}$, testifying the high values of the indicators. Further research should investigate the properties of pulp produced from $M . x$ giganteus biomass grown in soils contaminated with various TEs, as well as the possible translocation of elements to pulp.
\end{abstract}

Keywords: Miscanthus x giganteus, lead-contaminated soil, phytoremediation parameters, organosolvent cooking, pulp properties

\section{INTRODUCTION}

Currently, the growing process of converting energy crop biomass into bioproducts, which is described within the demands of the EU Bioeconomy Strategy, involves the production of renewable biological resources and their processing into vital products and bioenergy. ${ }^{1,2}$ This maximizes contributions toward the 2030 Agenda and Sustainable Development Goals and the Paris Agreement on climate change. The share of non-wood plant materials as alternatives to wood in pulp production to be processed into paper and other cellulose-containing products is increasing. This substitution will lead to diversification of the industry with simultaneous social and environmental benefits. ${ }^{3}$ Pulp for paper production is divided into three main categories: ${ }^{4}$ wood fiber, non-wood fiber, and wastepaper, and their shares in the pulp and paper industry are $63 \%, 3 \%$, and $34 \%$, respectively. The non-wood share has a considerable potential to increase ${ }^{5-8}$ because of the limitation of forest resources and a visible trend, from the bioeconomic perspective, toward decreasing the impact on climate change. ${ }^{1}$ The potential amount of non-wood raw materials that may be processed into pulp is about 2.5 billion tons per year and is renewed annually. ${ }^{9}$ The use of non-wood raw materials dates back to the origins of the paper industry and remains an urgent problem for the industry. ${ }^{5,6}$ Promising alternative plants include perennial energy crops, ${ }^{8-15}$ which have high lignin content and show good harvest in marginal and slightly contaminated lands. These findings were used to extend renewable biomass provision and ensure food security. The pulp from perennial grasses can be added to the existing wood feedstock ${ }^{13,14}$ or be processed individually.

Cellulose Chem. Technol., 55 (3-4), 271-280(2021) 
Among perennial grasses, Miscanthus $x$ giganteus has shown the highest harvest value. ${ }^{15,16}$ The crop has a good environmental profile with potential to increase soil carbon, fertility, and biodiversity, and to reduce nutrient runoff and leaching. It showed low fertilizer and pesticide demands ${ }^{16,17}$ during production. Being a C4 plant, $M . x$ giganteus contributes to the reduction in anthropogenic $\mathrm{CO}_{2}$ emissions, as the quantity of $\mathrm{CO}_{2}$ released by combusting biomass does not exceed the amount previously fixed by photosynthesis during plant growth. ${ }^{18}$ Multiyear growing of $M . \times$ giganteus enhances the cycling of nutrients in the plant-soil system. ${ }^{19}$

M. $x$ giganteus produces reasonable yields on different lands, i.e. from sands to high-organicmatter soils. ${ }^{20-24}$ The plant is tolerant of a wide range of $\mathrm{pH}$; the optimum $\mathrm{pH}$ range is between 5.5 and 7.5. It is usually harvested in late winter or early spring. The crop exhibited good production properties when used for remediation of brownfield sites, post-mining sites, former military sites, and contaminated agricultural lands. ${ }^{2}$ Our previous research ${ }^{25,26}$ demonstrated the suitable production of $M . x$ giganteus biomass in soils of different origins that were slightly contaminated with trace elements (TEs).

There are a few standard approaches to obtain pulp from wood and non-wood raw materials, i.e., sulfate, sulfite, and neutral-sulfite methods, and all negatively influence the environment by using sulfur-containing reagents for lignin removal from the plants' material. Most of the lignin is removed during cooking; however, there is some residual lignin, which can be removed by additional treatment by bleaching using chlorine-based and oxygen-based chemicals. ${ }^{27,28}$ Organosolvent delignification has been suggested as an environmentally friendly process and an alternative method to obtain pulp. Organic reagents have the potential to remove lignin and hemicelluloses at boiling temperature, and a variety of organic solvents, i.e., esters, alcohols, ketones, and organic acids, have been recommended for cooking. ${ }^{29,30}$ Due to its relatively low cost, acetic acid can be regarded as a potential agent to achieve extensive delignification; in particular, it is suitable for agricultural wastes. ${ }^{31}$ The application of hydrogen peroxide during cooking promotes delignification of raw materials; increased brightness can also be achieved by delignification with peroxy compounds. $^{32}$ At the same time, a less pronounced impact on cellulose is observed during cooking with these compounds. ${ }^{33}$ The cooking process is conducted at a low temperature, which helps to consume less energy; for example, Chempolis Ltd. uses peroxide-based cooking for chemical pulp production in Finland and China. ${ }^{34}$

The conversion of M. $x$ giganteus biomass to pulp was reported ${ }^{10,12-14}$ for the cases when the plant was grown on regular agricultural land. However, there is no research related to this crop biomass conversion to pulp when the feedstock was grown in contaminated soil. The main goal of the current study was the processing of $M . x$ giganteus biomass into pulp applied for phytoremediation of lead-contaminated soil. Also, the investigation of chemical composition, morphological structure, microscopic parameters of crop stalks; as well as their comparison with the corresponding parameters for other raw materials: rape, flax, hemp, wheat straw, and wood, was carried out.

\section{EXPERIMENTAL}

\section{Materials and methods}

M. $x$ giganteus biomass harvested after the second vegetation was investigated. The plant was applied as a phytoremediation agent to a lead-contaminated site located at the research field of the National University of Life and Environmental Sciences, Kyiv, Ukraine. The coordinates of the site are $50^{\circ} 22^{\prime} 59^{\prime \prime} \mathrm{N}, 30^{\circ} 30^{\prime} 29^{\prime \prime} \mathrm{E}$. The land is grey forest soil. M. $x$ giganteus rhizomes (variety Osinniy Zorezvit) were planted on April 28, 2016. The experiment was performed in three replications. Each plot had a surface area of $10 \mathrm{~m}^{2}$. The planting density rate was 15,000 plants/ha. The plant growing process occurred over two years, i.e., 20162017. Herbicides and insecticides were not applied during vegetation and weed control was provided manually. The plant showed a suitable establishment rate equal to $98 \%$ during both vegetation periods. After the first vegetation, biomass was cut manually on April 3, 2017; new plant sprouts appeared on April 10, 2017. During the second vegetation, the same agricultural technique was used. The dry biomass after the second vegetation was cut on April 9, 2018. This biomass was analyzed for the content of TEs and used for processing into pulp. The morphological indicators and dry matter yield were measured at harvest time.

\section{Soil and plant analysis}

The soil in the research field was of the grey forest podzolic type. Soil was analyzed in terms of its agrochemical parameters and content of TEs. The sampling was performed using the standard approach (DSTU ISO 11464, 2001). One testing square was selected with a size of $5 \times 5 \mathrm{~m}$; from this square, five soil samples were taken at the depth of 0-0.3 m using the 
envelope method, one in the center and four in the corners, and were then mixed and used for analysis. The agrochemical parameters of the soil are presented in Table 1. We concluded that, in accordance with the Standard of Ukraine (DSTU.47966:2008), the research soil was rich in $\mathrm{P}, \mathrm{K}$, and organic matter, and had low contents of $\mathrm{N}, \mathrm{S}$, and microelements; the contents of $\mathrm{Mg}$ and $\mathrm{Ca}$ were average.

\section{Analysis of soil and plant tissue for the content of elements}

The soil and plant tissues were prepared for analysis of lead and other trace elements in accordance with the standard ISO 11464-2001. The preparation procedure is described in detail in Pidlisnyuk et al. ${ }^{26}$ Briefly, the soil sample was dried at $105^{\circ} \mathrm{C}$ to constant mass, placed on a clean sheet of paper, and small stones, plant pieces, and other debris were removed. Then, mixed soil was put on a clean paper in the form of a square and divided into four equal parts using a spatula, two opposite parts were removed, while the two others were combined, mixed again, and taken further for analysis. This mixed sample was additionally sieved $(0.25 \mathrm{~mm}$ pore size $)$. The content of the trace elements in the soil was measured using Xray Röntgen fluorescence analysis, following the standard procedure. ${ }^{26}$ Data about the content of TEs in the soil for the examined plots are presented in Table 2.

We concluded that the investigated soil was strongly contaminated by $\mathrm{Pb}$; its concentration in the soil was about 20 times higher than the standard value, $30 \mathrm{mg} / \mathrm{kg} .{ }^{35}$ The contents of $\mathrm{Cu}$ and $\mathrm{Zn}$ were also rather high, although they did not exceed the standard limits. The contents of other monitored TEs were low. It was found earlier that M. $x$ giganteus grew well in artificially lead-contaminated soil in laboratory conditions. $^{36}$ This was the motivation to test the phytoremediation properties of the plant under the field conditions, when the primary soil contaminant was lead.

The plant's biomass was harvested in spring 2018 and the roots were analyzed for the content of TEs using the X-ray Röntgen fluorescence methods described above. The stalks, leaves, and roots were prepared for analysis in accordance with the procedure described earlier, ${ }^{25}$ specifically, in accordance with ISO 11464-2001 and ISO 11465-2001, respectively. The contents of lead and other TEs in different plant tissues are presented in Table 3. We found that the highest concentration of lead was detected in the plant's roots, and the content of lead in the aboveground part of the plant (leaves and stems) was limited.

Table 1

Agrochemical parameters of the research soil

\begin{tabular}{lccc}
\hline Parameters & Unit of measurement & Value & Method of analysis \\
\hline N nitrate & $\mathrm{mg} / \mathrm{kg}$ & 4.6 & DSTU2629-2014 \\
$\mathrm{N}$ alkaline hydrolysed & $\mathrm{mg} / \mathrm{kg}$ & 95 & DSTU 7863-2015 \\
$\mathrm{P}$ available & $\mathrm{mg} / \mathrm{kg}$ & 496 & DSTU 4115-2002 \\
K available & $\mathrm{mg} / \mathrm{kg}$ & 550 & DSTU 4115-2002 \\
Organic matter & $\%$ & 4.9 & DSTU 7623 \\
$\mathrm{pH}$ water extraction & $\mathrm{pH} \mathrm{unit}$ & 7.9 & DSTU 8346-2015 \\
pH salt extraction & $\mathrm{pH} \mathrm{unit}$ & 6.9 & GOST 26483-85 \\
Total salinity & $\mathrm{mg} / 100 \mathrm{~g}$ & 80 & DSTU 7627-2014 \\
Hydrolytic acidity & $\mathrm{m}-\mathrm{mole}$ & 0.16 & DSTU 7537-2014 \\
Sum of base saturation & $\mathrm{m}-\mathrm{mole}$ & 0.63 & GOST 22821-88 \\
S available & $\mathrm{mg} / \mathrm{kg}$ & 26 & DSTU 8347-2015 \\
Ca exchangeable & $\mathrm{m}-\mathrm{mole}$ & 0.3 & GOST 26487-85 \\
Mg exchangeable & $\mathrm{m}-\mathrm{mole}$ & 8.8 & GOST 26487-85 \\
\hline
\end{tabular}

Table 2

Content of TEs in the soil, ${ }^{*} \mathrm{mg} / \mathrm{kg}$

\begin{tabular}{cccc}
\hline Elements & Plot 1 & Plot 2 & Plot 3 \\
\hline $\mathrm{Mn}$ & $452.57 \pm 34.31$ & $764.93 \pm 50.32$ & $468.19 \pm 34.98$ \\
$\mathrm{Fe}$ & $15975.59 \pm 91.98$ & $16949.78 \pm 95.48$ & $17799.34 \pm 97.53$ \\
$\mathrm{Ni}$ & $16.29 \pm 8.40$ & $14.48 \pm 8.65$ & $17.34 \pm 8.73$ \\
$\mathrm{Cu}$ & $127.70 \pm 5.83$ & $134.80 \pm 6.21$ & $130.25 \pm 6.20$ \\
$\mathrm{Zn}$ & $130.15 \pm 6.33$ & $174.99 \pm 7.18$ & $146.42 \pm 11.64$ \\
$\mathrm{Sr}$ & $78.72 \pm 2.08$ & $80.72 \pm 2.11$ & $76.51 \pm 2.16$ \\
$\mathrm{Zr}$ & $665.84 \pm 4.01$ & $678.75 \pm 4.08$ & $660.72 \pm 4.10$ \\
$\mathrm{~Pb}$ & $604.16 \pm 9.60$ & $612.01 \pm 8.67$ & $583.15 \pm 8.83$ \\
\hline
\end{tabular}

${ }^{*}$ Measurements made in 2016 
VALENTINA PIDLISNYUK et al.

Table 3

Content of TEs in plant tissues, ${ }^{*} \mathrm{mg} / \mathrm{kg}$

\begin{tabular}{|c|c|c|c|}
\hline Elements & Leaves & Stalks & Roots \\
\hline & \multicolumn{3}{|c|}{ First replication } \\
\hline $\mathrm{Mn}$ & $17.17 \pm 5.93$ & $14.81 \pm 7.31$ & $44.65 \pm 2.47$ \\
\hline $\mathrm{Fe}$ & $40.69 \pm 9.38$ & $36.82 \pm 8.98$ & $1660.04 \pm 105.69$ \\
\hline $\mathrm{Ni}$ & $0.05 \pm 1.36$ & $0.08 \pm 1.52$ & $0.09 \pm 6.13$ \\
\hline $\mathrm{Cu}$ & $82.36 \pm 1.17$ & $80.00 \pm 1.60$ & $154.56 \pm 25.12$ \\
\hline $\mathrm{Zn}$ & $57.07 \pm 1.73$ & $58.58 \pm 2.24$ & $72.74 \pm 4.10$ \\
\hline $\mathrm{Sr}$ & $1.41 \pm 0.86$ & $1.06 \pm 0.95$ & $13.29 \pm 2.84$ \\
\hline $\mathrm{Zr}$ & $2.29 \pm 0.41$ & $1.89 \pm 0.66$ & $10.98 \pm 2.95$ \\
\hline \multirow[t]{2}{*}{$\mathrm{Pb}$} & $17.02 \pm 0.56$ & $13.94 \pm 0.58$ & $172.13 \pm 2.60$ \\
\hline & \multicolumn{3}{|c|}{ Second replication } \\
\hline $\mathrm{Mn}$ & $15.17 \pm 34.96$ & $19.77 \pm 6.61$ & $142.74 \pm 38.83$ \\
\hline $\mathrm{Fe}$ & $40.48 \pm 8.59$ & $53.89 \pm 7.10$ & $2917.82 \pm 180.06$ \\
\hline $\mathrm{Ni}$ & $0.03 \pm 2.73$ & $0.00 \pm 1.82$ & $0.10 \pm 11.83$ \\
\hline $\mathrm{Cu}$ & $72.95 \pm 7.14$ & $87.82 \pm 1.42$ & $289.82 \pm 9.43$ \\
\hline $\mathrm{Zn}$ & $26.95 \pm 2.93$ & $35.66 \pm 2.83$ & $110.68 \pm 7.50$ \\
\hline $\mathrm{Sr}$ & $1.28 \pm 0.33$ & $2.62 \pm 0.78$ & $9.37 \pm 5.12$ \\
\hline $\mathrm{Zr}$ & $0.40 \pm 1.16$ & $0.67 \pm 0.67$ & $19.83 \pm 5.48$ \\
\hline \multirow[t]{2}{*}{$\mathrm{Pb}$} & $12.20 \pm 1.04$ & $10.09 \pm 0.62$ & $120.34 \pm 4.72$ \\
\hline & \multicolumn{3}{|c|}{ Third replication } \\
\hline $\mathrm{Mn}$ & $12.20 \pm 3.30$ & $10.52 \pm 7.12$ & $130.38 \pm 25.72$ \\
\hline $\mathrm{Fe}$ & $59.26 \pm 13.32$ & $49.01 \pm 10.00$ & $2024.40 \pm 100.10$ \\
\hline $\mathrm{Ni}$ & $0.23 \pm 1.67$ & $0.20 \pm 1.35$ & $0.22 \pm 1.59$ \\
\hline $\mathrm{Cu}$ & $109.60 \pm 1.37$ & $92.30 \pm 1.13$ & $373.46 \pm 6.95$ \\
\hline $\mathrm{Zn}$ & $46.80 \pm 1.75$ & $28.37 \pm 2.19$ & $185.37 \pm 4.93$ \\
\hline $\mathrm{Sr}$ & $0.89 \pm 0.95$ & $35.22 \pm 0.73$ & $24.83 \pm 3.83$ \\
\hline $\mathrm{Zr}$ & $0.39 \pm 0.71$ & $0.00 \pm 0.62$ & $2.76 \pm 3.04$ \\
\hline $\mathrm{Pb}$ & $16.76 \pm 0.80$ & $12.94 \pm 0.50$ & $183.38 \pm 3.20$ \\
\hline
\end{tabular}

*Harvest of spring 2018

The detected concentrations were in the same range as those in the experiment of Nurzhanova et al. ${ }^{36}$

\section{Plant and pulp elemental analysis}

Samples of pulp with the weight of $1.1447 \mathrm{~g}$ (sample 1), $1.4786 \mathrm{~g}$ (sample 2), and $1.3762 \mathrm{~g}$ (sample 3) were selected. Samples were dried up to constant mass. Samples were combusted at $450{ }^{\circ} \mathrm{C}$, for 4 hours, cooled for 1 hour in a desiccator, and weighed. Ash samples were placed in a $32 \mathrm{~mm}$ cuvette, covered with a thin film (Prolene Thin-Film, Chemplex Industries, USA), compacted, and analyzed using the X-ray Röntgen fluorescence analysis described above.

\section{Chemical composition}

The chemical compositions of the main components of $M$. x giganteus stalks and other non-wood plants were determined according to TAPPY standards. ${ }^{37}$ Each part of the stalk was tested in three replications to determine the average value and the measurement error of the results for each indicator.

\section{Scanning electron microscopy}

Scanning electron microscopy (SEM) analyses were performed using a PEM-106I microscope (SELMI,
Ukraine) to observe the morphological structure of various components of the M. x giganteus stalks.

\section{Cooking method}

The pulp from $M . x$ giganteus stalks was cooked using the peracetic method, which is more environmentally safe than traditional sulfate and sulfite methods of cellulose production ${ }^{38}$ and is characterized by lower energy costs compared with conventional and organosolv methods of delignification. ${ }^{39}$ A peracetic acid solution was used as cooking liquor. It was prepared by mixing ice acetic acid and $30 \mathrm{wt} \%$ hydrogen peroxide; the volumetric ratio was 70\%:30\%. The cooking solution was kept in a dark cupboard for several days to achieve the peracetic acid concentration of $11 \mathrm{wt} \%$. The resulting solution was subsequently diluted with distilled water to reduce the peracetic acid concentrations to the desired values and used in the cooking process. Glass flasks with a volume of $1 \mathrm{dm}^{3}$ were loaded with $20 \mathrm{~g}$ of $M . x$ giganteus stalks, which were precrushed into pieces that were $15-20 \mathrm{~mm}$ long. Cooking liquor was then added; the ratio of liquids to solids was 10:1. The flasks were placed in a water bath and heated to $95{ }^{\circ} \mathrm{C}$ for $30-240$ min. To ensure a proper cooking process and to eliminate the loss of the cooking liquor solution, the flasks were connected to reflux. After reaching the 
cooking time, the flasks were removed and cooled under a stream of cold water, the spent liquors were separated, and the pulp was washed with distilled water to achieve a neutral medium. Then, the pulp was dehydrated and dried in air to a constant moisture content of 5-7\%. Such a mode of peroxide pulping was considered to be optimal based on the results reported by previous studies ${ }^{40}$ related to the effects of different volume ratios of acetic acid and hydrogen peroxide, boiling water modulus, and cooking temperature. The pulp was beaten in a Valley beater at $6 \%$ consistency to $60 \mathrm{SR}$. Handsheets of peracetic $M$. $x$ giganteus pulp of $75 \pm 1$ $\mathrm{g} / \mathrm{m}^{2}$ were formed on a Rapid-Köthen unit.

\section{Evaluation of physical and mechanical properties}

The physical and mechanical parameters of the pulp obtained from $M . x$ giganteus biomass were determined according to TAPPI standards. ${ }^{37}$ Each organosolvent pulp was tested, with a minimum of five specimens, to determine the average value and the measurement error of the results for each physical and mechanical property.

\section{RESULTS AND DISCUSSION}

\section{Agrochemical parameters of $M$. $x$ giganteus}

Despite the soil being contaminated with lead, in a rather high concentration, along with other TEs in lower concentrations, the plant properly developed in this soil during two vegetation periods and showed sufficient yield of biomass. The morphometric growth indicators and dry biomass yield are presented in Table 4. The findings confirmed the laboratory results of Nurzhanova et al. $^{36}$ and showed that the existence of lead, along with other TEs, did not affect much the plant's growth and development. The morphometric indicators and dry biomass yield had higher values in the second vegetation, which was previously observed for $M . x$ giganteus multiyear growth. ${ }^{41}$ Comparing the results presented in Tables 3 and 4, we concluded that $M$. $\times$ giganteus shows good growth in soil contaminated with lead and other TEs and that the concentration of TEs in the aboveground part of biomass is limited. As such, we argue that the phytoremediation process can be defined as phytostabilization and that the soil was stabilized; however, the contaminants did not move to the aboveground part of the plants and remained concentrated in the roots. Thus, the produced biomass may be processed into pulp.

\section{Morphological analysis of various parts of M. $x$ giganteus stalks}

The stalks of the plants are the main raw material in the pulp and paper industry. $M . \times$ giganteus stalks consist of internodes (part of the stalks between the nodes), nodes and leaves. SEM photos of various parts of $M . x$ giganteus stalks are presented in Figure 1. A layer of epidermal cells is located on the surface of the stalks, which is covered with a hydrophobic cuticle with stomata: microscopic holes that regulate gas and vapor exchange between the plant and the environment due to changes in the turgor of the guard cells (Fig. 1a). In the epidermis layer, there are cells of a nailshaped form and remnants of bundles of chlorenchyma and sclerenchyma. Chlorenchyma cells are large and well-developed. The sclerenchyma is located around the conducting bunches and adjacent threads of a chlorenchyma. The main components are xylem cells and phloem cells, which perform the conductive, mechanical, and storage functions in the stalks of plants. These include tracheid cells, vascular cells, libriform cells, and parenchymal cells (Fig. 1b). The presence of such cells is typical of different representatives of non-wood raw materials.

Table 4

Morphological parameters and dry matter yield of $M . x$ giganteus

\begin{tabular}{cccccc}
\hline $\begin{array}{c}M . x \text { giganteus } \\
\text { growth } \\
\text { indicators }\end{array}$ & $\begin{array}{c}\text { Plant } \\
\text { height, } \\
\mathrm{cm}\end{array}$ & $\begin{array}{c}\text { Number } \\
\text { of stalks }\end{array}$ & $\begin{array}{c}\text { Number } \\
\text { of leaves }\end{array}$ & $\begin{array}{c}\text { Leaf width, } \\
\mathrm{mm}\end{array}$ & $\begin{array}{c}\text { Aboveground dry } \\
\text { matter yield, } \\
\text { t/ha }\end{array}$ \\
\hline 2016 & $159.1 \pm 1.7$ & $9 \pm 0.1$ & $20 \pm 0.3$ & $25 \pm 0.1$ & $6.9 \pm 0.7$ \\
2017 & $180 \pm 2$ & $19 \pm 0.2$ & $14 \pm 0.7$ & $25 \pm 0.3$ & $13.0 \pm 0.5$ \\
\hline
\end{tabular}

The nodes of $M . x$ giganteus stalks (Fig. 1c) mainly consist of short cells of the collenchyma, which perform mechanical and storage functions, ensuring the elasticity of the plant walls, and contain a large amount of pectin and water. The core of M. $x$ giganteus (Fig. 1d) contains short parenchymal cells that perform the function of storing nutrients. The microscopic study of the stalk structure illustrates that the outer surface of the stalk is covered with a layer of small cells of the 
epidermis that perform a protective function. The bulk of the stalk consists of tracheal, vascular, libriform, and parenchymal cells, which are common for other non-wood raw materials. Therefore, we concluded a priori that $M . x$ giganteus biomass is suitable for processing into pulp, which can be used for production of cardboard and papers.

\section{Chemical composition}

The chemical composition of $M . x$ giganteus stalks, non-wood plants, hardwood, and softwood species is presented in Table 5. The content of cellulose (the main component of plant raw materials) in the mixture of different parts of $M . x$ giganteus stalks exceeds the content of cellulose in mixtures of wheat straw, rapeseed, and hemp, as well as softwood and hardwood. However, it is similar to the content of cellulose in a mixture of flax. M. $x$ giganteus stalks have relatively high lignin content, which is close to the lignin contents of rapeseed and spruce stems. It has the mineral content (in terms of ash) close to those of other non-wood plants and significantly exceeding those of softwood and hardwood.
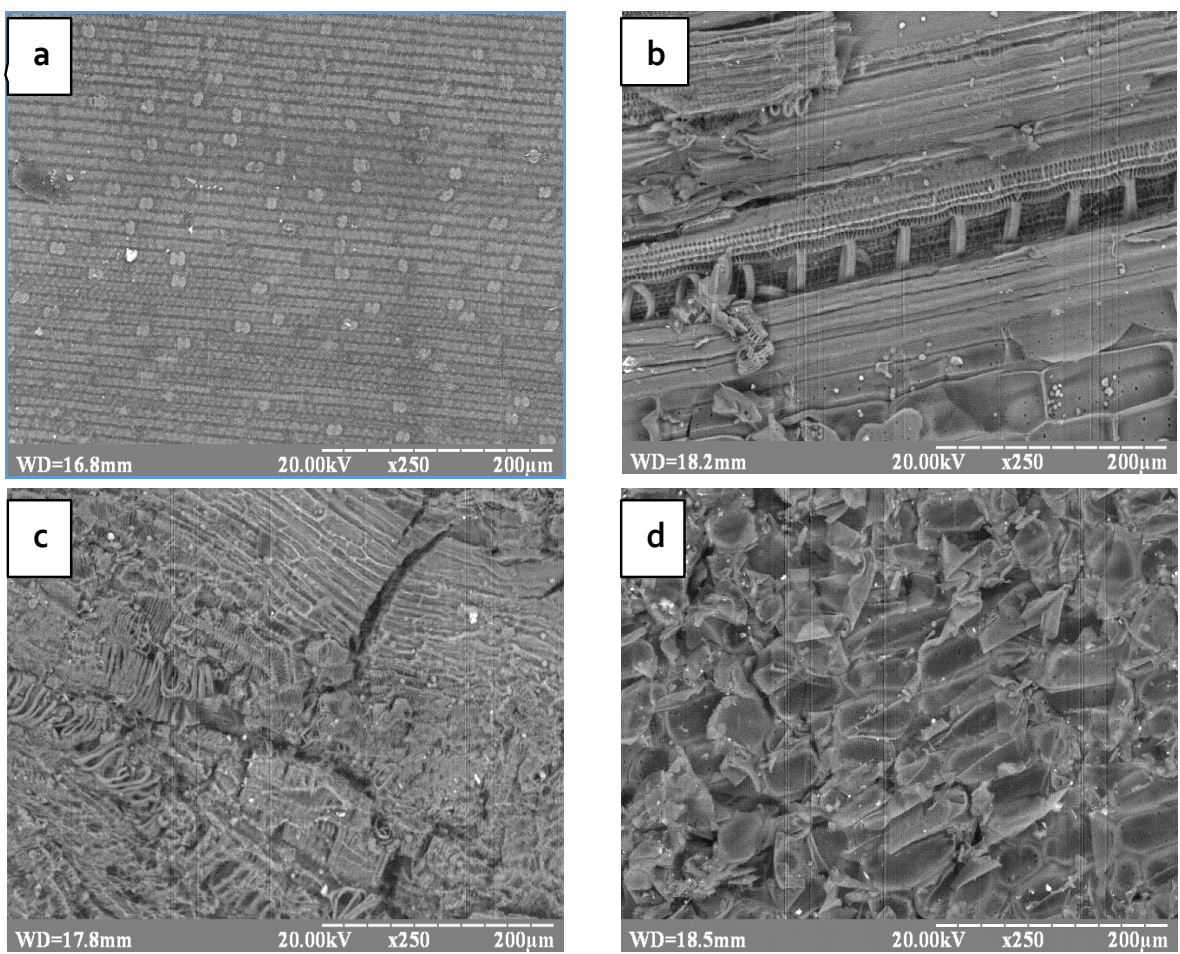

Figure 1: SEM images of different parts of M. x giganteus stalk: outer part of the stalk (a), internodes (b), nodes (c) and core (d)

\section{Effect of cooking duration on pulp properties}

The obtained data showed that increasing the cooking time from 30 to $240 \mathrm{~min}$ decreased the $M$. $x$ giganteus pulp yield from $54.3 \%$ to $43.0 \%$ on mass of absolutely dry raw materials, due to the increased dissolution of lignin, extractive substances, mineral components, and partial destruction of polysaccharides. A decrease in residual lignin from $0.5 \%$ to $0.1 \%$ on the mass of absolutely dry raw materials during cooking increased the brightness of pulp from $78.3 \%$ to $83.1 \%$. The brightness of the obtained peracetic pulps had higher values in comparison with those of unbleached pulp obtained by other methods of delignification (sulfate, sulfite, or neutral-sulfite) from different plant materials. The process of delignification of $M . x$ giganteus stalks by the peracetic method occurs without complications and shows significant differences from that of other non-wood plant raw materials. ${ }^{42}$ The cooking process using peracetic pulp is more economically advantageous compared to traditional sulfate and sulfite methods and other organosolvent methods of delignification from raw plant materials, which are usually carried out at temperatures of $140-180{ }^{\circ} \mathrm{C}$ for 3-6 hours. ${ }^{27}$

Dependencies of pulp properties: total yield $\left(Y_{1}\right)$, residual lignin content $\left(Y_{2}\right)$, and ash $\left(Y_{3}\right)$, on 
the cooking time $(t)$ using $M . x$ giganteus biomass and wheat straw biomass can be described by regression equations with the general formula: ${ }^{43}$

$\mathrm{Y}_{\mathrm{i}}=a+b * t$

These regression equations are as follows:

for $M$. x giganteus:

$Y_{1}=53.65-0.05 * t \quad(R=-0.9361)$

$Y_{2}=0.48-0.001 * t \quad(R=-0.9212)$

$Y_{3}=1.11-0.002 * t \quad(R=-0.9622)$

and for wheat straw:

$Y_{1}=82.92-0.22 * t \quad(R=-0.9734)$

$Y_{2}=1.86-0.01 * t \quad(R=-0.9847)$
$Y_{3}=4.38-0.02 * t \quad(R=-0.9562)$

As shown in Equations (2)-(7), the dependences of variable functions of $Y_{i}$ on the duration of organosolvent cooking $(t)$ are described by a linear regression equation with a correlation coefficient $(R)$ close to -1.0 . A negative value of the correlation coefficient $R$ means that with growth of one of the variables (cooking time), the other variable $\left(Y_{\mathrm{i}}\right)$ decreases. This coefficient $R$ is close to 1 , which means that the relationship between the variables can be interpreted as being quite close to linear. ${ }^{43}$

Table 5

Chemical composition of non-wood plant raw materials and wood, \% from mass of absolutely dry raw materials

\begin{tabular}{|c|c|c|c|c|c|c|}
\hline \multirow{2}{*}{ Plant part } & \multirow{2}{*}{ Cellulose } & \multirow{2}{*}{ Lignin } & \multicolumn{2}{|c|}{ Solubility in } & \multirow{2}{*}{$\mathrm{RFW}^{*}$} & \multirow{2}{*}{ Ash } \\
\hline & & & water & $\mathrm{NaOH}$ & & \\
\hline \multicolumn{7}{|c|}{ M. $x$ giganteus } \\
\hline Mixture & $53.3 \pm 1.47$ & $25.5 \pm 0.645$ & $3.3 \pm 0.49$ & $25.1 \pm 0.79$ & $1.86 \pm 0.15$ & $1.71 \pm 0.14$ \\
\hline Internodes & $55.8 \pm 1.48$ & $25.1 \pm 0.63$ & $3.0 \pm 0.48$ & $24.1 \pm 0.78$ & $2.04 \pm 0.16$ & $1.60 \pm 0.13$ \\
\hline Knots & $46.6 \pm 1.39$ & $27.0 \pm 0.65$ & $4.2 \pm 0.51$ & $27.9 \pm 0.81$ & $1.81 \pm 0.17$ & $1.77 \pm 0.15$ \\
\hline \multicolumn{7}{|c|}{ Wheat straw } \\
\hline Mixture & $44.3 \pm 1.33$ & $16.5 \pm 0.58$ & $10.1 \pm 0.5$ & $38.4 \pm 0.99$ & $5.2 \pm 0.2$ & $6.6 \pm 0.18$ \\
\hline Stalk & $46.2 \pm 1.34$ & $18.6 \pm 0.60$ & $6.0 \pm 0.48$ & $36.2 \pm 0.98$ & $4.6 \pm 0.19$ & $4.2 \pm 0.17$ \\
\hline Leaves & $42.3 \pm 1.35$ & $15.2 \pm 0.59$ & $9.8 \pm 0.52$ & $40.1 \pm 1.05$ & $6.5 \pm 0.19$ & $9.4 \pm 0.19$ \\
\hline \multicolumn{7}{|c|}{ Rape } \\
\hline Stalk & $35.6 \pm 1.28$ & $22.9 \pm 0.65$ & $11.6 \pm 0.52$ & $25.6 \pm 0.81$ & $4.8 \pm 0.19$ & $3.3 \pm 0.16$ \\
\hline Root & $28.3 \pm 1.29$ & $27.7 \pm 0.71$ & $10.9 \pm 0.53$ & $31.5 \pm 0.82$ & $2.4 \pm 0.21$ & $5.4 \pm 0.18$ \\
\hline \multicolumn{7}{|c|}{ Flax } \\
\hline Mixture & $59.6 \pm 1.41$ & $10.9 \pm 0.58$ & $4.1 \pm 0.49$ & $13.6 \pm 0.77$ & $4.7 \pm 0.19$ & $2.4 \pm 0.14$ \\
\hline Fiber & $69.5 \pm 1.52$ & $6.1 \pm 0.61$ & $3.7 \pm 0.43$ & $13.4 \pm 0.66$ & $3.6 \pm 0.11$ & $1.5 \pm 0.12$ \\
\hline Wood part & $42.0 \pm 1.36$ & $23.6 \pm 0.73$ & $5.2 \pm 0.54$ & $19.4 \pm 0.82$ & $5.2 \pm 0.24$ & $2.8 \pm 0.15$ \\
\hline \multicolumn{7}{|c|}{ Hemp } \\
\hline Mixture & $46.2 \pm 1.33$ & $17.0 \pm 0.53$ & $6.9 \pm 0.49$ & $25.0 \pm 0.69$ & $2.2 \pm 0.13$ & $2.6 \pm 0.12$ \\
\hline Bast & $67.8 \pm 1.51$ & $6.5 \pm 0.48$ & $3.8 \pm 0.47$ & $20.8 \pm 0.57$ & $1.9 \pm 0.12$ & $1.5 \pm 0.11$ \\
\hline Wood part & $42.2 \pm 1.34$ & $12.5 \pm 0.69$ & $5.1 \pm 0.53$ & $22.9 \pm 0.72$ & $3.7 \pm 0.15$ & $2.9 \pm 0.14$ \\
\hline \multicolumn{7}{|c|}{ Wood } \\
\hline Birch tree & $41.0 \pm 1.29$ & $21.0 \pm 0.54$ & $2.2 \pm 0.52$ & $11.2 \pm 0.68$ & $1.8 \pm 0.15$ & $0.5 \pm 0.07$ \\
\hline Spruce & $46.1 \pm 1.35$ & $28.5 \pm 0.61$ & $7.3 \pm 0.54$ & $18.3 \pm 0.59$ & $2.9 \pm 0.18$ & $0.2 \pm 0.05$ \\
\hline
\end{tabular}

$* \mathrm{RFW}$ - resins, fats, waxes

The value of the free term $a$ in Equation (1) is positive $(a>0)$ for Equations (2)-(7), meaning that the relative change in the results of $Y_{\mathrm{i}}$ is slower than the change in the factor $t{ }^{43}$ In this case, the value of the coefficient $b$ in Equation (1) characterizes the change in the value of pulp properties $Y_{i}$ from the change in the cooking time factor $t$. Analysis of Equations (2)-(7) suggests that an increase in the cooking time $t$ has a more significant effect on reducing the yield of pulp $\left(Y_{1}\right)$ than reducing its content of mineral substances $\left(Y_{3}\right)$ or residual lignin $\left(Y_{2}\right)$. The absolute values of the coefficients $a$ and $b$ in the regression equations for M. $x$ giganteus (Eqs. (2)-
(4)) are less than for the regression equations for wheat straw (Eqs. (5)-(7)). This indicates that conducting the organosolvent delignification of M. $x$ giganteus stalks resulted in the production of pulp with a lower content of residual lignin and mineral substances compared to the delignification of wheat straw.

The difference in the indicators for the pulps obtained from M. $x$ giganteus and wheat straw can be explained by a more complete process of $M . x$ giganteus stalk delignification (increased removal of lignin from the structure of $M . x$ giganteus raw materials) due to lower contents of resins, fats, and waxes in $M . x$ giganteus, and increased penetration 
of the cooking solution to the macromolecules of M. $x$ giganteus lignin, compared to other non-wood materials, such as wheat straw.

This statement is confirmed by the lignincarbohydrate diagram (Fig. 2) of peracetic delignification of various non-wood plants, constructed according to the procedure described by Barbash et al. ${ }^{39}$ The proposed methodology for evaluating the efficiency of the process of plant raw material delignification allows comparing the process of obtaining pulp from different materials by delignification on one lignin-carbohydrate diagram or obtaining pulp from one raw plant material by different methods.

The line of ideal delignification in the diagram describes the maximum content of polysaccharides of in pulp for a certain content of residual lignin. Therefore, the closer the line of the particular delignification process to the line of ideal delignification for a certain value of residual lignin, the greater the yield of polysaccharides in the resulting pulp due to preservation of cellulose and hemicelluloses. For M. $x$ giganteus and wheat straw, the dependence of pulp yield on the content of lignin is on almost the same line and has higher yield values than the process of delignification of rape stalks. We concluded that the peracetic method of delignification of M. $x$ giganteus biomass is not inferior to obtaining pulp from wheat straw; however, it is better in comparison with the delignification of rape stalks (Fig. 2).

\section{Physical properties of peracetic $M . x$ giganteus pulp and content of $\mathbf{P b}$}

The organosolvent peracetic pulp obtained from M. $x$ giganteus biomass with a cooking time of 90 minutes was selected for the investigation of physical properties. The strength properties of handmade sheets from peracetic pulps had the following physical and mechanical parameters: breaking length of $8300 \mathrm{~m}$, tear resistance of 310 $\mathrm{mN}$, and burst resistance of $220 \mathrm{kPa}$. The obtained data demonstrated the suitability of the physical and mechanical indicators and the possibility of using this pulp in further production of paper and cardboard.

The pulp was analyzed for the content of lead and other TEs; the results are presented in Table 6. Comparing the data presented in Table 6 with those in Table 4, some peculiarities of translocation of TEs from $M$. $x$ giganteus stalks to pulp can be observed, i.e. concentrations of $\mathrm{Mn}, \mathrm{Fe}, \mathrm{Ni}, \mathrm{Cu}, \mathrm{Zn}$ $\mathrm{Sr}$, and $\mathrm{Zr}$ decreased in the pulp in comparison with the stalks, so those metals were removed from the pulp under the influence of chemicals. At the same time, the concentration of lead remained almost the same in the obtained pulp and initial $M . x$ giganteus biomass, so lead was not dissolved by chemicals during pulping. For further understanding of the peculiarities of TEs translocation from $M . x$ giganteus biomass to pulp, additional research in which differently contaminated biomasses will be converted to pulp is needed.

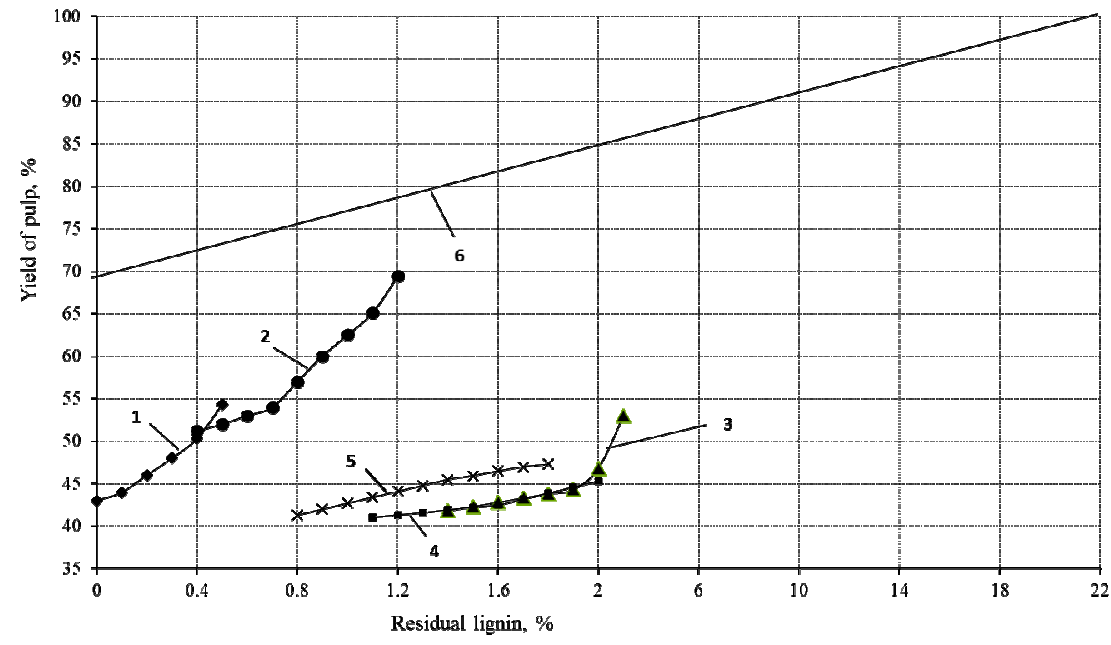

Figure 2: Lignin-carbohydrate diagram of peracetic delignification of different non-wood plants:

1- . x giganteus; 2- wheat straw; ${ }^{40} 3$ - rape without catalyst; ${ }^{32} 4$ - rape with catalyst $\mathrm{Na}_{2} \mathrm{WO}_{4},{ }^{32} 5$ - rape with catalyst $\mathrm{Na}_{2} \mathrm{MoO}_{4} ;{ }^{32} 6$ - line of "ideal delignification" 
Table 6

Content of TEs in the pulp produced from $M . x$ giganteus $(\mathrm{mg} / \mathrm{kg})$

\begin{tabular}{ccccc}
\hline Elements & Sample 1 & Sample 2 & Sample 3 & Average value \\
\hline $\mathrm{Ti}$ & $3.64 \pm 1.12$ & $2.97 \pm 1.08$ & $3.53 \pm 1.40$ & $3.38 \pm 1.20$ \\
$\mathrm{Mn}$ & $2.24 \pm 0.25$ & $2.21 \pm 0.23$ & $2.96 \pm 0.31$ & $2.47 \pm 0.26$ \\
$\mathrm{Fe}$ & $16.02 \pm 0.35$ & $16.13 \pm 0.33$ & $25.02 \pm 0.47$ & $19.06 \pm 0.38$ \\
$\mathrm{Ni}$ & $0.24 \pm 0.08$ & $0.28 \pm 0.08$ & $0.29 \pm 0.10$ & $0.27 \pm 0.09$ \\
$\mathrm{Cu}$ & $88.77 \pm 0.43$ & $81.31 \pm 0.39$ & $104.67 \pm 0.50$ & $91.58 \pm 0.44$ \\
$\mathrm{Zn}$ & $23.14 \pm 0.21$ & $20.94 \pm 0.19$ & $28.55 \pm 0.26$ & $24.21 \pm 0.22$ \\
$\mathrm{Sr}$ & $0.22 \pm 0.01$ & $0.19 \pm 0.01$ & $0.24 \pm 0.02$ & $0.22 \pm 0.01$ \\
$\mathrm{Sn}$ & $0.71 \pm 0.06$ & $0.62 \pm 0.06$ & $0.76 \pm 0.07$ & $0.70 \pm 0.06$ \\
$\mathrm{~Pb}$ & $13.06 \pm 0.12$ & $11.68 \pm 0.12$ & $15.08 \pm 0.16$ & $13.28 \pm 0.13$ \\
\hline
\end{tabular}

\section{CONCLUSION}

In this research work, the conversion of $M . x$ giganteus biomass produced in soil contaminated with lead and other TEs into pulp, using peracetic treatments, was described. The M. $x$ giganteus phytoremediation parameters were measured and showed that the phytostabilization process occurred, which permitted using the almost clear aboveground biomass for processing into pulp. The delignification of the initial raw material allowed obtaining pulp with low lignin and ash contents and high brightness, with low energy costs and a short cooking time. Increasing the time of peracetic cooking reduced the content of lignin and increased of brightness in the peracetic M. $x$ giganteus pulp. The physico-mechanical properties of $M . \quad x$ giganteus pulp met the requirements for paper production and subsequent chemical processing. The applied cooking process using peracetic pulp is ecologically and economically advantageous, compared to traditional sulfate and sulfite methods. Further research is needed to investigate the processing of $M . x$ giganteus biomass grown in soils differently contaminated by TEs to pulp in order to explore the process of possible translocation of TEs from biomass to pulp.

ACKNOWLEDGEMENTS: The research was supported by project G4687, NATO SPS MYP; CORNET MiscanValue; and project N2002, Ministry of Education and Science of Ukraine. The authors are thankful to Dr. Shapoval, National University Lvivska Polytechnika, Ukraine, for providing X-ray Röntgen fluorescence analysis.

\section{REFERENCES}

L. Caudet and V. von Hammerstein-Gesmold, A new bioeconomy strategy for a sustainable Europe,
Eur. Comm. Press Release, 716 (2018), https://eur-lex europa eu/legal-content/EN/TXT

2 S. Rusinowski, J. Krzyzak, K. Sitko, H. M. Kalaji, E. Jensen et al., Environ. Pollut., 250, 300 (2019), https://doi.org/10.1016/j.envpol.2019.04.048

3 K. Saijonkari-Pankala, Agric. Food Sci. Finl., 10 (2001)

4 Z. Liu, H. Wang and L. Hui, in "Pulp and Paper Processing”, IntechOpen, 2018, pp. 3-7, http://doi.org/0.5772/intechopen.79017

5 A. Ashori, Polym.-Plast. Technol., 45, 10 (2007), https://doi.org/10.1080/03602550600728976

6 O. L. M. Kamoga, J. K. Byaruhanga and J. B. Kirabira, Int. J. Chem. Eng. Appl., 4, 3 (2013), http://hdl.handle.net/20.500.12283/103

7 C. Ververis, K. Georghiau, N. Christodoulakis, P. Santas and R. Santas, Ind. Crop. Prod., 19, 3 (2004)

8 W. Sridach, Suranaree J. Sci. Technol., 17, 2 (2010)

D. Danielewicz, B. Surma-Slusarska, G. Zurek, D. Martynial, M. Kmiotek et al., BioResources, 10, 4 (2015), http://doi.org/10.1007/s10570-018-2023-9

10 K. N. Law, B. V. Kokta and C. B. Mao, Bioresour. Technol., 77, 3 (2001), https://doi.org/10.1016/S09608524(00)00140-1

11 D. Danielewicz, K. Dybka-Stepien and B. SurmaSlusarska, Cellulose, 25, $673 \quad$ (2018), https://doi.org/10.1007/s10570-018-2023-9

12 P. Cappelletto, F. Mongardini, B. Barberi, M. Sannibale, M. Brizzi et al., Ind. Crop. Prod., 11, 2 (2000), https://doi.org/10.1016/S0926-6690(99)000515

13 J. Bocianowski, E. Fabicial, K. Joachimiak, R. Wojech and A. Wojciak, Cellulose Chem. Technol., 53, $271 \quad$ (2019), https://doi.org/10.35812/CelluloseChemTechnol.2019. 53.27

14 F. Marin, J. L. Sanchez, J. Arauzo, J. R. Fuertes and A. Gonzalo, Bioresour. Technol., 100, 3933 (2009), https://doi.org/10.1016/j.biortech.2009.03.011

15 O. Daraban and Ș. Jurcoan, Agronomy Series of Scientific Research, 58, 2 (2015) 
16 V. Kvak, T. Stefanovska, V. Pidlisnyuk, Z. Alasmary and M. Kharytonov, INMATEH, 54, 1 (2018)

17 E. Heaton, T. Voigt and S. P. Long, Biomass Bioenerg., 27, 21 (2004), https://doi.org/10.1016/j.biombioe.2003.10.005

18 A. Kiesel and I. Lewandowski, GCB Bioenerg., 9, 1 (2017), https://doi.org/10.3389/fpls.2017.00347

19 P. Kahle, S. Beuch, B. Boelcke, P. Leinweber and H.-R. Schulten, Eur. J. Agron., 15, 3 (2001), https://doi.org/10.1023/B:MITI.0000038848.94134.be

20 B. Kołodziej, J. Antonkiewicz and D. Sugiera, Ind. Crop. Prod., 81, 3 (2016), https://doi.org/10.1016/j.indcrop.2015.11.052

21 F. Nsanganwimana, B. Pourrut, M. Mench and F. Douay, J. Environ. Manag., 143, 10 (2016), https://doi.org/10.1016/j.jenvman.2014.04.027

22 V. Pidlisnyuk, J. Trogl, T. Stefanovska, P. Shapoval and L. Erickson, Nova Biotechnol. Chim., 15, 1 (2016), https://doi.org/10.1515/nbec-2016-0008

${ }^{23}$ V. Pidlisnyuk, T. Stefanovska, E. Lewis, L. Erickson and L. Davis, Crit. Rev. Plant. Sci., 33, 1 (2014), https://doi.org/10.1080/07352689

24 A. Burges, I. Alkorta, L. Epelde and C. Garbisu, Int. J. Phytoremediat., 20, 384 (2018), https://doi.org/10.1080/15226514.2017.1365340

25 V. Pidlisnyuk, L. Erickson, J. Trögl, P. Shapoval, L. Davis et al., Pol. J. Chem. Technol., 20, 1 (2018), https://doi.org/10.2478/pjct-2018-0016

26 V. Pidlisnyuk, L. Erickson, T. Stefanovska, J. Popelka, G. Hettiarachchis et al., Environ. Pollut., 249, 6 (2019), https://doi.org/10.1016/j.envpol.2019.03.018

27 G. A. Smook, in "Handbook for Pulp and Paper Technologists", edited by M. J. Kocurek, Canadian Pulp and Paper Association, 1982, pp. 58-75

28 A. Antunes, E. Amaral and M. Belgacem, Ind. Crop. Prod., $12, \quad 85 \quad$ (2000), https://doi.org/10.1016/S0926-6690

29 J. Snelders, E. Dornez, B. Benjelloun-Mlayah, W. J. J. Huijgen, P. J. de Wild et al., Bioresour. Technol., 156 , 275

(2014),

https://doi.org/10.1016/j.biortech.2014.01.069

30 C. Nitsos, R. Stoklosa and A. Karnaouri, ACS

Sustain. Chem. Eng., 4, 5181 (2016), https://doi.org/10.1021/acssuschemeng.6b01205
31 M. S. Jahan, J. N. Rumee, M. M. Rahman and A. Quaiyyum, Cellulose Chem. Technol., 48, 111 (2014), https://www.cellulosechemtechnol.ro/pdf/CCT12(2014)/p.111-118.pdf

32 I. Deykun, V. Galysh and V. Barbash, Cellulose Chem. Technol., 52, $833 \quad$ (2018), https://www.cellulosechemtechnol.ro/pdf/CCT910(2018)/p.833-839.pdf

33 R. Kumar, F. Hu, C. A. Hubbell, A. J. Ragauskas and C. E. Wyman, Bioresour. Technol., 130, 372 (2013), https://doi.org/10.1016/j.biortech.2012.12.028

34 Chempolis Biorefining Processes, available at https://chempolis.com/technologies-solutions/

35 GOST 17.4.1.02-83, USSR, Protection of the environment. Soils. Classification of the chemical substances for the control of pollutants

36 A. Nurzhanova, V. Pidisnyuk, K. Abit, C. Nurzhanov, B. Kenessov et al., Environ. Sci. Pollut. Res., 26, 27555 (2019), https://doi.org/10.1007/s11356-019-06230-7

37 TAPPI Test Methods, Atlanta, Georgia, Tappi Press, 2004

38 V. A. Barbash, V. V. Poyda and I. M. Deykun, Cellulose Chem. Technol., 45, 613 (2011), https://www.cellulosechemtechnol.ro/pdf/CCT45,910(2011)/p.613-618.pdf

39 V. Barbash, I. Trembus, S. Alushkin and O. Yashchenko, Science Rise, 3/2, 71 (2016), https://doi.org/10.15587/2313-8416.2016.63098

${ }^{40}$ V. Barbash, I. Trembus and N. Sokolovska, Cellulose Chem. Technol., 52, 673 (2018), https://www.cellulosechemtechnol.ro/pdf/CCT78(2018)/p.673-680.pdf

${ }_{41}$ I. Lewandowski, J. C. Clifton-Brown, J. M. O. Scurlock and W. Huisman, Biomass Bioenerg., 19, 209 (2000), https://doi.org/10.1016/S0961-9534(00)000325

V. Barbash, I. Trembus and Y. Nagorna, Chem. Chem. Technol., 6, 83 (2012)

43 M. A. Zaid, "Correlation and Regression Analysis", SESRIC, Ankara, 2015, pp. 4-12 